\title{
Study on Present Situation of Discretion in Urban Management Comprehensive Law Enforcement
}

\author{
Nan Jiang \\ Shandong Agricultural University, Shandong, China \\ jiangnan94819@163.com
}

\begin{abstract}
Keywords: Urban management; Comprehensive Enforcement; Discretion; Administration by Law and constitution; Present Situation.
\end{abstract}

\begin{abstract}
This paper is based on analyzing the meaning of discretion and then analyzes three points of discretion's legal basis of urban management personnel, the manifestation of discretion and right relief, and then we can conclude three conclusions that legal system which regulates urban management personnel is still imperfect, discretional behaviors are influenced by various factors and administrative law enforcement's efficiency is low and the cost is high. Then we can provide methods of analyzing the urban management personnel's enforcement logic and a necessary way of advancing the process of new urbanization.
\end{abstract}

\section{Introduction}

Recently, relevant reports about urban management personnel's comprehensive enforcement can be shown and caused enthusiastic social discussion in the first time. Based on the variation of basic management environment that urban management personnel met and law enforcement behaviors, urban management personnel should be endowed with certain discretion to deal with basic management work of trivial, multifarious and relating to livelihood. Because the discretional behaviors of urban management personnel play an important role in keeping social fair, justice and normal social order, and the behaviors are related to administration counterpart's welfare, it's necessary to study the behaviors and its' logic behind of one line administration personnel represented as urban management and how they use discretion on the street to reveal that why the urban management officer is a nice man today but be a murder of beating innocent people tomorrow and why a urban management officer can get along well with business men in some time and some place but in another time and place they're at daggers drawn., then we can thoroughly solve the dilemma of urban management personnel, even the one line administrative enforcement dilemma [1]. Meanwhile, in the decade of carrying out new urbanization, the study of urban management personnel's behaviors' rationality and legitimacy has significant importance in limiting the discretion, protecting the rights of administrative counterparts and improving urban management efficiency.

\section{The Meaning of Discretion}

Administrative discretion is the disposal power with selections nation endows administrative organ within the amplitude and range of legal provisions. This is the important component of administrative power, the administrative subject's authority of improving administration efficiency and the modern administration's inevitable requirement. "Black Law Dictionary" of America defined it as" a power that makes contribution in a proper and fair way according to authority under special circumstance". Fawcett and Wade defined the discretion as "a right of selecting positive action, negative action and how to behave under legal permission, it's a certain degree of autonomy within a certain framework and content" [2]. Demark thought that for administration, the definition of discretion is to choose freely or taking actions freely according to the best optimum of one's own [3]. M. Y. Wang thought that "law cannot regulate something specifically that what decision officers should make, officers can rely on their own judgments to select the most favorable decision they 
think among all possible decision for executing duty" [4]. In a word, administrative discretion is that administrative subjects choose power among all possible measures according to legitimate authority and legal condition within the amplitude and range of law. It's the core of modern administrative power which is the real and substantial power.

\section{The Legal Basis of Urban Management Personnel's Discretion}

The Legal Basis of Urban Management Personnel's Comprehensive Enforcement. According to the principle of administrative law, administrative law enforcement's basis is to obey specific rules, then the principles and last the discretion. Most laws and regulations which regulate administrative actions emphasize the law principles the administrative subjects should obey in the general principles, such as legitimacy, justice, publicity, impartiality, promptness and convenience, combine education and punish together, combine grooming and governance together, civilized law enforcement and so on. When the law regulations are not perfect, law principles, the generalization of law regulations, can lead the urban management administration for administrative law enforcement. However, in reality, urban management personnel's administrative authorities are the management rights on some specific problem such as city appearance, health, greening and public order. A lot of social basic relationship producing between these management authorities can't be merely regulated by law norms, so it's necessary to use discretion based on actual conditions [5]. In this way, we can make specific administrative action properly. Law regulations and law principles provide legal and rational guarantee for urban management personnel's discretion.

The Legal and Policy Basis of Urban Management Personnel's Discretion. At present, laws that regulate urban management personnel in our country are imperfect. Based on the particular requirements of urban management administrative law enforcement, urban management personnel often use discretion on the base of law principles under the circumstance that law system and regulations are not perfect. In China, there're several points to regulate urban management subject of enforcement:

Firstly, study the legal and policy basis from the aspect of policy environment. Under some circumstances, policies are transferred by the broad legal commands. Expect expressing public private should be satisfied; policy can rarely take guidance for urban management personnel's comprehensive law enforcement. The exercising of discretion can make up the vulnerability of public policy so that urban management personnel's service management strategy can be supported [6].

The Forth Plenary Session of the 18th Central Committee of the Communist Party put forward that the persistence of ruling by law should base on the persistence of ruling of constitution and the persistence of governing by law should base on governing by constitution. The constitution provided expressly that China's basic situation is in the primary stage of socialism, provided that we should insist on the reform and opening, determined the practicing of the system of socialist market economy, determined the basic plan ruled by law and established a socialist country ruled by law. "The country respects and guarantees the human rights" and "Protecting people's legitimate private property against invasion" were written in Chinese constitution [7].In a word, the exertion of discretion should respect constitution and law and guarantee human rights.

On December 18, 2015, the central economic working conference was held in Beijing. Its major task is to conclude the achievement of economic work in current year, to analyze economic situation home and abroad and to make planning of macroeconomic economy development. The economic strategies determine the urban management, and the aim of urban management personnel's exertion of discretion is serving national economic instruction. There're direct mentoring relationships between them. Following is on December 23, 2015, the central urban working conference was held in Beijing after 37 years. The conference analyzed severe situation of urban development, accomplished urban management work of guiding ideology, general idea and main task, had practice 
both instruction and management, transformed the mode of urban development, perfected the urban governance system, improved the urban governance's abilities and solved prominent problems like "urban disease". Urban management personnel, the terminal link of urban manage system; have a direct impact action on directly facing all kinds of urban problems. Urban management is by no means the pure administrative law enforcement and management, but the core method of promoting new urbanization under new situation.

Secondly, study the legal and policy basis from the aspect of People's Congress's legislations. The article 16 in the Law of the People's Republic of China on Administrative Penalty shows that "The State Council or the people's government of a province, autonomous region or municipality directly under the Central Government that is empowered by the State Council may decide to have an administrative organ exercise other administrative organs' power of administrative penalty. However, the power of administrative penalty involving restriction of freedom of person shall only be exercised by the public security organs". The second item of Article 17 in the Law of the People's Republic of China on Administrative Compulsion shows that "Administrative organs which exercise relatively centralized powers of administrative punishment in accordance with the Law of the People's Republic of China on Administrative Punishment may implement administrative coercive measures related to their powers of administrative punishment as prescribe by law and regulations".

Thirdly, study the legal and policy basis from the aspect of the State Council's administrative legislations. <Regulation on Investigating and Treating and Banning Unlicensed Business>shows that though the regulation is made to regulate administrative actions of industry and business management, it's a core legal basis of urban management personnel in reality.

A series of normative documents of order universal binding force formed in administrative order: The Information of Staying Experimental Work about Relatively Concentrated Administrative Punishment Power which made by general office of the State Council on September $8^{\text {th }}, 2001$. Study on Further Promoting Work of Relatively Concentrated Administrative Punishment Power which made by general office of the State Council on August, 2002; The State Commission Office of Public Sectors Reform (SCOPSP) and the Office of Legal System in the State Council released the notice of Study on relevant problems promoting Relatively Concentrated Administrative Punishment Power and comprehensive law enforcement experimental work on February, 2003.

Last but not least, study the legal and policy basis from the aspect of local regulations made by provinces. In provincial level, the regulations in<City Appearance and Environmental Sanitation Management Regulation in Shandong Province>regulate urban management personnel's discretional behaviors and in municipal level, <Regulation on Performing Urban Management Relatively Concentrated in Administrative Punishment Power in Tai'an > instructs urban management personnel's discretional behaviors.

\section{The Classification of Urban Management Personnel's Discretional Behaviors}

The specific administrative actions of discretion made by urban management personnel are the different manifestation in different situation. Based on law-enforcement practice in reality, discretional behaviors of urban management personnel can be divided into several sorts and arranged according to the violent degree of behaviors from weak and strong. See in Table.1.

We can learn from urban management personnel's work that there're several points why personnel take mild discretional actions: (1)The illegal activities are slight; (2)Personnel's attitude of realizing mistakes is positive and they correct their illegal actions timely; (3)Based on the weakness of peddlers, urban management personnel will protect them in law enforcement strategies. With the accumulating of factors above, personnel's law enforcement strategies are getting harder. But in reality, because the existence of some unforeseen extrinsic factors and the pressure of public opinion, urban management personnel are forced to take some hard discretional actions without other methods. 
Table 1 The classification of one line urban management personnel's discretional behaviors

\begin{tabular}{|c|c|c|c|}
\hline Discretion & Methods & Reasons and interpretation & $\begin{array}{l}\text { The violent degree of } \\
\text { discretion }\end{array}$ \\
\hline Tolerant & $\begin{array}{l}\text { Neglect the illegal } \\
\text { activities. }\end{array}$ & Out of sympathy. & \multirow[t]{7}{*}{ weak } \\
\hline Educate & $\begin{array}{l}\text { Oral criticism to } \\
\text { correct errors by } \\
\text { peddlers themselves. }\end{array}$ & $\begin{array}{l}\text { For slight behaviors violating regulations or } \\
\text { for peddlers' positive attitude towards } \\
\text { acknowledging error and correcting timely. }\end{array}$ & \\
\hline Assistant & $\begin{array}{l}\text { Choose operation } \\
\text { places for floating } \\
\text { peddlers. }\end{array}$ & $\begin{array}{l}\text { On the one hand, it's convenient to } \\
\text { governance city appearance and manages } \\
\text { peddlers. On the other hand, it can support } \\
\text { peddlers to make a living. }\end{array}$ & \\
\hline Goad & $\begin{array}{l}\text { Goad peddlers away } \\
\text { from their operation } \\
\text { places by oral and } \\
\text { limb methods. }\end{array}$ & $\begin{array}{l}\text { Aiming at floating peddlers who deals in the } \\
\text { street. Goading them away from their } \\
\text { original management places in order to } \\
\text { maintenance social and management order. }\end{array}$ & \\
\hline patrol & $\begin{array}{l}\text { Patrol in the scoping } \\
\text { by driving to warn } \\
\text { peddlers. }\end{array}$ & $\begin{array}{l}\text { To prevent peddlers' behaviors which } \\
\text { overtly agree but covertly oppose. }\end{array}$ & \\
\hline $\begin{array}{c}\text { Seizure } \\
\text { temporarily }\end{array}$ & $\begin{array}{l}\text { Seizure temporarily if } \\
\text { the persuasion for } \\
\text { dealing in the street or } \\
\text { doing business } \\
\text { unlicensed failed, or } \\
\text { the fine execution and } \\
\text { correction failed. }\end{array}$ & $\begin{array}{c}\text { Seizure peddlers' management apparatus } \\
\text { temporarily to punish their illegal } \\
\text { management behaviors. }\end{array}$ & \\
\hline Fine & $\begin{array}{l}\text { Fine administrative } \\
\text { counterparts according } \\
\text { to Administrative } \\
\text { Punishment Law. }\end{array}$ & $\begin{array}{l}\text { On the one hand, peddlers refuse to correct } \\
\text { despite of repeated violations, persuasion } \\
\text { and oral education failed. On the other hand, } \\
\text { the illegal activities of peddlers seriously } \\
\text { hampered normal public order. }\end{array}$ & \\
\hline
\end{tabular}

\section{The Methods of Discretion's Right Relief in Urban Management Comprehensive Law Enforcement}

We can learn from the discretions of urban management personnel and strategies of the administration counterpart that discretion's manifestations are various without regulations of specific laws. Some scholars deny the application of discretion because it's conflicting between discretion and law. Any substantive discretional behaviors are related to autocracy and being the threat to individual freedom [5]. In modern society, nobody will deny the correctness of discretion's existence. Because of the properties, objective and the policy and helper of urban management, it's necessary to exert discretion. Power is accompanied with remedying so that specific administrative actions are effect binding. There're three ways of right remedying of discretion.

Administrative Reconsideration. Administrative reconsideration is an institution that when the administrative counterparts disaffect the administrative actions' litigation or the rationality, they can ask review agency to take legitimate examination and make decision [8]. According to legal provisions, if the administrative counterparts disaffect specific administrative discretional actions in the urban management work, they can ask government or higher authorities' administrative organs of administrative authorities that made specific administrative actions for administrative reconsideration. Higher authorities' administrative organs or government should make examination on both legitimacy and rationality. If they think the specific administrative actions are unreasonable or illegal, 
the specific administrative actions should be treated as cancelled and administrative authorities that made specific administrative actions will be required to compensate for loss and make a humble apology. In reality, the number of administrative reconsiderations is small because most discretional behaviors during the administrative law enforcement of urban management show as oral discouraging instead of normative documents so that programmed essentials of administrative reconsideration can't form. The level of discretions often depends on urban management personnel's political consciousness and professional level, so the procedure of administration by law needs thinking that the meaning of "law" in urban management administration should include legal norm, general law principles, law spirit, legal purpose and a consideration of loving people.

Administrative Litigation. According to legal provisions, if the administrative counterpart is disaffected about the specific administrative behaviors of urban management personnel's discretion, they can put forward administrative litigation to people's court. Article 5 in Administrative Procedure Law of the People's Republic of China shows that "in handling administrative cases, the people's courts shall examine the legality of specific administrative acts." Hence in China establish the legitimate checking principle in administrative litigation and eliminate the reasonable review of urban management discretion [9]. People's court can check the legality of discretional behaviors in urban management based on the Constitution Law, laws and regulations and then give a judgment on the illegal specific administrative actions.

The constitutional basis of Administrative Procedure Law of the People's Republic of China is the Article 41: "Citizens of the People's Republic of China have the right to criticize and make suggestions regarding any state organ or functionary. Citizens have the right to make to relevant state organs complaints or charges against, or exposures of, any state organ or functionary for violation of the law or dereliction of duty" "Citizens who have suffered losses as a result of infringement of their civic rights by any state organ or functionary have the right to compensation in accordance with the law" [10]. It can be seen that the aim of establishing administrative litigation system is to remedy private rights. In folk, administrative litigation system is called the institution of "layman suing officials", the relief function of protecting private rights is obvious [11]. In modern society, the number of cases of administrative litigation is small. Only when the written decision of administrative penalty is prepared or limb conflicts take place will citizens take the weapon of procedure law to defend their legal rights.

Public Opinion. Public opinion supervision is the core important component of socialist democracy. Our Party, government and urban management personnel can only develop job under the supervision of public opinion and citizens can safeguard their legal rights and interests by means of public opinion. In reality, news about urban management personnel's law enforcement activities can be shown in reports, including some situations didn't accord with reality and made people misunderstand the law enforcement of urban management personnel. "Street-level bureaucrat" locates in the base and at the same time they're civil servants having dealings with citizens among government employee [6]. It's exactly urban management personnel are in the terminal link of public power, which can radiate the broadest masses of the people and relate to numerous households' livelihood, so the number of public opinions and supervisions is big and the exertion of discretion is cautious.

Conclusions and Suggestions. After the study of exercising discretion in present situation, we can get several following conclusions: (1) Legal system which regulates urban management personnel is still imperfect. During the process of urban management personnel's enforcement, the exercising of discretion has no law regulations to be regulated, but has law principles and policies to be guided. Urban management personnel are in a dilemma of enforcement; their discretion's exercising is under great pressure of public opinion. (2) In the complex and dynamic basic management environment, urban management personnel unfold a series of discretional behaviors aiming at specific work constrained by multiple factors, not only includes the influence and restriction of specific regional environment such as enforcement region, enforcement time and enforcement resources, but the 
pressure of public opinion as well. (3) Administrative law enforcement's efficiency is low and the cost is high. Some discretionary actions of urban management personnel such as "assistance", "driving" and "patrolling" can't reach the goal of management. Problems happened behind these are the imperfect market management, the unsoundness of urban planning and the unreasonable allocating laid-off workers. Otherwise, the satisfaction degree of urban management personnel's enforcement is low, the effect of enforcing law can't be saved for a long time and the basic management is lacking a long-acting operation mechanism.

Aiming at several problems above, some suggestions can be put up as the followings: (1) Perfect relative laws of urban management as quickly as possible to regulate urban management personnel's discretion in the form of law. (2) Guide public opinion positively and treat urban management discretion, the special role of "street-level bureaucrat", dialectically. (3) Improve administrative law enforcement efficiency and reduce the cost of administrative management.

\section{References}

[1] N. B. Chen and S. Y. Lu. Tacit Interaction in Field Conversion-Discretional Behaviors of Chinese "Urban Management Personnel" and Its Logic. Management world. vol. 10, pp. 68-80, 2013.

[2] H.W.R. Wade. Administrative Law New York: Oxford University Press, 1988.

[3] Marashall E Dimork, Law and Dynamic Administration, P131, P137, New York, Publishers, 1980.

[4] M. Y. Wang. American Constitution (second volume). China Legal Publishing House. 1995.

[5] J. R. Hou and W. H. Liu. The Application of Discretion in Urban Management Personnel's Comprehensive Law Enforcement. Fujian Forum (humanities and social sciences). vol. 12, pp. 194-199, 2012.

[6] J. J. Wang. Review of street-level bureaucrats' discretion. Xichang College Journal (social science edition). vol. 22 No. 2, pp. 73-76, 2010(6).

[7] X. T. Wang. Comment of Special Column on October 29, 2014.

[8] H. K. Yang and H. S. Zhu. Administrative Reconsideration's Conception Adjustment and System Perfection. Law review. No. 4, pp. 18-32, 2014.

[9] J. J. Ouyang. Citizen Participation's Control on Administrative Discretionary Right. Politics and Law. No. 10, 2011.

[10] See article 41 in Chinese Constitution Law.

[11]G. L. Xue. Consideration of Administrative Procedure law Revision's Basic Problem. Jurisprudence of China. No. 3, pp. 229-246, 2014. 